\title{
(Dis)Assembling policy pipelines: unpacking the work of management consultants at public meetings
}

\author{
Chris Hurl \\ Department of Sociology and Anthropology, Concordia University, Montréal, Canada \\ Correspondence to: Chris Hurl (chris.hurl@concordia.ca)
}

Received: 2 June 2016 - Revised: 31 January 2017 - Accepted: 2 February 2017 - Published: 3 May 2017

\begin{abstract}
Confronting growing fiscal deficits in the wake of the 2008 economic crisis, local governments around the world have often commissioned outside experts - such as policy gurus, management consultants, and transnational professional service firms - to undertake services delivery reviews as a means of making "tough" decisions, identifying the areas of government spending that are most expendable and setting priorities for cutbacks. This paper draws from the recent literature on trans-urban policy pipelines in studying the role of service delivery reviews in thickening relations of knowledge production between city regions (McCann and Ward, 2011, 2013; Prince, 2012). Taking the encounter with Toronto's 2011 Core Service Review as a starting place, it sets out to examine the textually mediated practices through which policy knowledge is generated. Drawing from Allen and Cochrane's (2010) topological approach, it highlights how management consultants make use of evaluative texts, lifting out and folding in knowledge and ideas from other places to make their presence felt. However, while these texts are presented as a "pure lens of cost savings", the work of rendering the city of Toronto commensurate with other distant places is often based on fragile and tenuous connections. Hence, against assumptions that these texts facilitate the foreclosure of possible utterances that can be made, I also explore the public meeting as a site for investigating alternative ways of knowing the city, providing a window onto the way in which oppositional registers of the city are themselves generated through translocal practices.
\end{abstract}

\section{Introduction}

Rather than viewing the KPMG report as a hit list of over-expenditures and fat needing to be trimmed, I see most of it as an identification of the very fabric of this city, its very soul.

- Deputation to City of Toronto Executive Committee, 28 July 2011

On 28 July 2011, Toronto city councillors assembled for what would be the longest continuous meeting in the history of the amalgamated city. For over $22 \mathrm{~h}$, some 169 deputants spoke to a KPMG report that classified each of the city's services on the basis of their "essentiality" and "standard" of delivery and suggested various opportunities for cutbacks and restructuring (Dale and Rider, 2011). In the 3 min that were allotted to each of them, all but a few derided the mayor and city councillors for a misguided experiment, noting that the report misdiagnosed the problems facing the city and failed to consider the full impact of potential cuts. Deputant after deputant raised the question, were "above standard" city services really reflective of "fat needing to be trimmed", or were they a source of community pride to be protected and cherished?

Confronting growing fiscal deficits in the wake of the 2008 economic crisis, city governments around the world have often commissioned services delivery reviews to assist them in making "tough decisions". Enlisting the advice of outside experts - such as policy gurus, consultants, think tanks, and professional service firms - they have attempted to generate strategies for cost savings, program streamlining, and service delivery reform. Indeed, a growing body of literature has explored the prominent position of these sorts of intermediaries in emergent trans-urban policy pipelines, rendering cities comparable and measurable according to a gen- 
eralized logic of benchmarks and best practices (Cocharane and Ward, 2012; McCann, 2008; McCann and Ward, 2011; Peck and Theodore, 2015; Prince, 2010). Through their capacity to mobilize knowledge across jurisdictions, such actors are often viewed as facilitating the generation of "fast policy", which is characterized by "the intensified and instantaneous connectivity of sites, channels, arenas, and nodes of policy development, evolution, and reproduction" (Peck and Theodore, 2015:223). But while policy-making is increasingly interlinked, this does not mean that the dominant policy ideas are simply reproduced from one place to the next. Far from a transparent flow of information, the process of rendering disparate local contexts commensurable and subject to assessment often requires a significant amount of work (McCann and Ward, 2012; Peck, 2011; Peck and Theodore, 2012; Prince, 2010). Consultants must skillfully re-fashion accounts from elsewhere in order to embed them in different institutional settings.

In this article, I take public meetings as one specific setting in which the knowledge claims of consulting firms are packaged and put into circulation. Rather than viewing consultants as impartial actors who bring in outside policy ideas, I look at public meetings as a relational space through which the positions of "inside" and "outside" are actively negotiated and contested. Drawing from Allen and Cochrane's (2014:1620) topological approach, I argue that power is derived from the capacity to lift out knowledge and agendas from other places and times and fold them into the policymaking process (see also Allen, 2010, 2011; Allen and Cochrane, 2010). Through condensing an array of disparate relationships and making them appear as a single transparent field of judgment, consultants are then able to forcefully make claims and generate credibility.

I illustrate my argument through my research on the politics of municipal service delivery reviews (MSDRs) in the Canadian city of Toronto. Facing a projected CAD 774 million deficit, the city commissioned KPMG in 2011 to undertake a 2-month-long review of its 155 services - ranging from waste collection to heritage sites, childcare, and social housing. Applying a "core service filter", consultants identified areas for potential cutbacks and cost savings by delimiting those aspects of municipal spending that were considered to be "discretionary" or "above standard". What was really necessary for the functioning of the city? What could the city do without? However, while consultants aimed to provide an objective lens for determining core service levels, the credibility of the review was widely contested, with the process condemned by many as merely "smoke and mirrors" to legitimize the mayor's agenda for cutbacks (Doolittle, 2011).

Taking the public meeting of 28 July 2011 as a case study, I trace the different ways in which various actors - including consultants, city councillors, community groups, and local residents - publicly testified to the city's needs. Drawing from analysis of official texts, including the KPMG report, municipal records, video recordings of the $22 \mathrm{~h}$ long meet- ing, and 10 interviews with both civic officials and community members, I explore the various strategies through which these actors sought to generate credibility by appealing to both distance and proximity. Specifically, I begin by highlighting the significance of accounting schema and modes of calculation deployed by management consultants in making a case for potential cuts. As I demonstrate, these templates have provided a means of "folding in" data from previously distant locations and making them appear close and comparable, contributing to the formation policy pipelines that facilitate the smooth circulation of service delivery ideas and agendas across jurisdictions (Cook and Ward, 2012; Ward, 2006).

Nevertheless, while these calculative schema are presented as a "pure lens" through which to set city priorities, the work of renderings the city of Toronto commensurate with other distant places is based on fragile and tenuous connections. Hence, against assumptions that these sorts of metrics facilitate the foreclosure of possible claims that can be made, I also take the public meeting as a site for investigating alternative ways of knowing the city. Taking examples from the deputations made, I explore how community members have worked to both disassemble the schema deployed by consultants while at the same time folding their own accounts into the policy-making process. I conclude by discussing the outcomes of the meeting with a focus on critically locating policy ideas through these kinds of public interventions.

\section{Urban intermediaries: inside and out}

How should critical researchers understand the position and influence of private intermediaries such as management consultants in urban governance? Much of the literature over the past 40 years has focused on the relationship between insides and outsides (see Eyal and Buchholz, 2010; Sturdy et al., 2009). The emphasis here is on the presumed objectivity of "outside" actors, who are brought "in" to provide policy advice. To what extent should they be considered neutral and independent third parties in the evaluation of city programs and services? Do they provide an accurate appraisal of things or is their advice compromised by underlying political and economic affiliations? Along similar lines, a number of studies have also investigated the role of large consulting firms in importing managerial frameworks taken from other places, which are then transplanted, like cookie cutters, to very different contexts (see Boussebaa, 2015; Kipping and Wright, 2012). In this section, I will critically appraise these two approaches with a focus on management consultants. Rather than focusing on the role of consultants as outside actors who transplant policies from one place to another, I am instead interested in the skillful practices through which they seek to "fold in" knowledge taken from other places in advancing their credibility in the policy-making process. 
A range of studies has interrogated the outsider status of policy intermediaries by seeking to uncover their underlying political and economic affiliations (Craig, 2006; Domhoff, 1967; Guttman and Willner, 1976; O'Shea and Madigan, 1997; Pinault, 2000). In the scholarship, there is tendency to advance what Eyal and Buchholz (2010:121) describe as a "problematic of allegiance". From this perspective, scholars investigate the degree of autonomy that think tanks, management consultants, and other outside experts and policy professionals possess in relation to so-called special interest groups and political and economic elites. Their ability to stand apart from such interests presumably speaks to their credibility in presenting a neutral perspective. If they position themselves at arm's length from vested interests, then their views are considered to be more impartial and worthy of consideration.

Intermediaries are incriminated to the extent that they maintain close connections with political and economic elites. Thus, it is often argued that management consultants are mere handmaidens that serve to legitimate the ideas of entrenched political and economic interests (Rassam and Oates, 1991; Sturdy et al., 2009). McKenna (2006:231) notes that consultants have increasingly generated business through their role as "independent outsiders" responsible for "selling legitimacy, not simply knowledge transfer". From this perspective, consultants are tasked with endorsing decisions that have already been made by elected officials and corporate boards. Far from commanding any authority, then, they are deployed by political elites as "window-dressing" that lend support and credibility to programs of administrative reform.

Conversely, others argue that management consultants form a distinctive class, or "consultocracy", who increasingly infiltrate state institutions, opening up private markets for policy advice (Hood and Jackson, 1991; Greer, 1994; Leys, 1999; Hodge and Bowman, 2006). In the context of neoliberal restructuring, consultants skillfully and self-servingly interject themselves in areas of policy-making that were previously undertaken by in-house civil servants. For instance, in his investigations of state restructuring across the UK through the 1980s and 1990s, Hood (1994:138) views the rise of consultants as part of a "new class" who "colonized the public management from the outside". State reforms, he notes, have been centrally driven by a "privatization complex" - "comprised of management consultants, accountants, and IT specialists who form the equivalent of "efficiency experts" "that seek to extend their managerial influence across state institutions as a means of drawing in new business. More recently, Raco (2013:18) has explored how this complex of experts operates as part of an "expanding machine" in the context of UK urban governance, reflecting a managerial agenda through which power is being "transferred from citizens and governments to regulators and a new breed of powerful global companies and investors", effectively removing decision-making from democratic oversight by elected polit- ical officials and their constituencies (see also Raco et al., 2016)

The language of "outside" infiltration can similarly invoke the spectre of large consulting firms operating through transnational networks that colonize different local settings, eradicating the distinctiveness of places by subsuming them under homogenous managerial frameworks. From this perspective, consultants are viewed as "agents of global knowledge diffusion" and as central to the transmission of global best practices and benchmarks (Greer, 1994; Kipping and Wright, 2012; Saint-Martin, 2000). A number of studies have recently noted the influence of professional service firms such as KPMG as intermediaries, who act as "brokers between diverse fields of action" (Savage and Williams, 2008:3; see also Larner, 2015; Larner and Laurie, 2010; Prince, 2010; Allen, 2010; Allen and Cochrane, 2010; Moss et al., 2011). Consultants, it is argued, are able to position themselves as powerful actors through their capacity to bridge what were previously separate and unconnected sites, to bring them into alignment, drawing upon organizational resources to negotiate and persuade other actors to pursue certain goals. Thrift (2005:93) describes them as "capitalism's commissars" since they are a central part of the "cultural circuit of capital ... able to produce constant discursivecum-practical change with considerable power to mold the content of people's work lives". Through their capacity to marshal economies of scale in packaging and mobilizing policy ideas, they are viewed as facilitating a process of policy convergence. In this sense, DiMaggio and Powell (1983:152) have likened consulting firms to "Johnny Appleseeds" that "spread a few organizational models throughout the land". Moreover, as the majority of these firms originated from and continue to be headquartered in the United States, and to a lesser extent in the United Kingdom, they are often viewed as agents of colonization, actively exporting Anglo-American styles of management to other parts of the world (Boussebaa, 2015).

Certainly, it is important to consider the influence of transnational professional service firms in shaping the contemporary policy landscape through their capacity to command resources and networks that traverse jurisdictions and crosscut various institutional settings. For instance, between 2011 and 2016, KPMG has been commissioned to undertake MSDRs in at least 26 cities and towns across the province of Ontario alone (KPMG, 2016). Through rolling out these kinds of evaluative programs, KPMG and other Big Four firms - EY, PwC, and Deloitte - have increasingly positioned themselves as brokers of public knowledge across local governments. Indeed, one of their chief selling points is that they are able to mobilize extensive professional networks in different cities around the world (Kennedy Consulting, 2013). As an international cooperative, KPMG employs nearly 174000 people and in 2015 generated revenue of USD 5.35 billion in auditing, taxation, and advisory services for the "infrastructure, government, and health care" 
sector alone (KPMG, 2015). This gives them a considerable economy of scale in packaging and circulating policy knowledge (McKenna, 2006; Saint-Martin, 2000; Suddaby and Greenwood, 2001), providing policymakers with access to data from a wide range of different jurisdictions and the knowledge and experience of KPMG specialists across the globe that have "resident expertise in specific domains, be it transportation, law enforcement, water, and so on". 1

However, it should not be assumed that professional service firms are able to transparently and seamlessly mobilize knowledge from one place to the next. Rather than beginning from the premise that these firms have access to knowledge across diverse contexts by virtue of their position as transnational actors, it is important to recognize how these data are highly mediated - generated and circulated through a disparate array of people, texts, and technologies. In these large firms, Jones (2002:348) notes, command and control is by its nature "a negotiated, complex and diffuse process that arises through a relational network of (admittedly differently significant) scattered social and non-human actors". In this sense, the mobilization of knowledge becomes a practical problem: how can management consultants acting in these firms make sense of a range of diverse data taken from other contexts and gather them together in advancing a forceful position?

Rather than interrogating the status of management consultants as outsiders who bring knowledge into different institutional contexts, I find it interesting here to consider how the line between "insides" and "outsides" is itself relationally negotiated through the course of assessment (Sturdy et al., 2009). From this perspective, public meetings like the one in Toronto provide important resources for urban scholars, activists, and community members in exploring the techniques through which management consultants seek to position themselves as credible actors. Council meetings, stakeholder consultations, professional conferences, and other events provide a milieu in which an array of official texts, testimonies by state and non-state actors, and governmental technologies of evaluation and assessment are gathered together, often making disparate claims in generating prescriptions for the treatment of urban problems. These are sites at which local experiences of urban life are accounted for in various ways, taken up by experts and officials who command different kinds of authority. They are places in which evaluative texts are presented, positioning the city within a generalized field of comparisons. They are also sites where the credibility of policy actors and their accounts are often contested and alternative views are mobilized.

Rather than viewing consultants as agents of knowledge diffusion, spreading ideas from context to context, I draw from Allen and Cochrane's (2010) topological approach in exploring how consultants make their case at public meetings through mobilizing ideas and agendas taken from a variety

\footnotetext{
${ }^{1}$ KPMG, 28 July 2011; presentation to the City of Toronto's Executive Committee.
}

other places and times and rendering them relationally proximate and commensurable. This perspective is not so much concerned with understanding the location of consultants in space. As Allen (2011:284) notes, "[d]istanciated ties and real-time connections are not understood as lines on a map which cut across territories, but rather as intensive relationships which create the distance between powerful and not so powerful actors". The focus, then, is on how power is generated through the capacity to draw some things together (i.e. policy ideas, managerial approaches, regulatory frameworks, governmental actors) and make them appear close, while setting others aside and making them appear far away (Sturdy et al., 2009). Through "mediated relationships which create the distance, near and far, between political actors", consultants generate a sense of presence, appearing able to traverse contexts and bring them into relation with one another (Allen and Cochrane, 2014:1620).

As I show in the next section, this sense of presence is accomplished in public meetings through the deployment of specific calculative schema and managerial technologies. Through appealing to various metrics and modes of calculation, consultants are capable of gathering together ideas and agendas from disparate places and times and presenting them all at once from a common vantage point. In this sense, they are able to "make their presence felt in more or less powerful ways that cut across proximity and distance" (Allen, 2010:284; see also Allen and Cochrane, 2010). The production of such artifacts involves work of "lifting out" knowledge from elsewhere and skillfully "folding" it into the municipal decision-making process. Through condensing an array of disparate relationships and making them appear to constitute a single transparent field of judgment, consultants are then able to forcefully make claims and generate credibility. By folding disparate knowledge into different institutional settings in this way, I argue that consultants are able to fashion "policy pipelines", facilitating the smooth circulation of ideas from one jurisdiction to the next (Cook and Ward, 2012; Ward, 2006).

\section{Assembling policy pipelines: "lifting out" and "folding in" policy knowledge}

In 2011, the city of Toronto hired KPMG to conduct a 2-month-long, CAD 3 million study of the city's services. Commissioned to identify areas of cost savings in confronting a projected CAD 774 million budget deficit, the study framed the debate over service delivery around the question of "core" requirements and "standards" of delivery. As KPMG (2011a:7) notes in its "Final Report to the City Manager", the purpose was "to review and analyze all city of Toronto services, activities, and service levels provided by divisions and agencies and to apply a core service filter to assist Council's decision-making". As a schema for assessing services, the filter was produced and deployed in pub- 
lic meetings in order to demonstrate how the city's 155 programs measured up. Were the services that the city provided really necessary? Could they be provided at lower standards? Should they be provided directly by public agencies or were they better left to alternative delivery models? In this section, I explore how the core service filter was mobilized as an technological artifact by which KPMG consultants could make their presence felt in the policy-making process through both drawing on the weight of examples from other, previously distant, jurisdictions and setting this knowledge apart from community input.

Including a number of different metrics and comparative registers, the core service filter enabled the mobilization of data from a variety of contexts in rendering different services commensurable. Perhaps the most important component was a "pictorial representation", which charted the position of each of the city's services in terms of its relative necessity, its standard of delivery, and its footprint on the city's budget. The relative position of a disparate array of services was presented on a two-dimensional graph, which plotted the necessity of the service (as "mandatory", "essential", "traditional", or "other") on the $y$ axis and the standard of delivery ("below", "above" or "at") on the $x$ axis. The information was graphically displayed in such a way that any services that were considered to be mandatory/below standard fell on the top-left side of the image and any services deemed discretionary/above standard fell on the bottom-right. Policymakers could then directly compare different services, such as waste management, public health, community grants, dental services and public parks. If a service was listed as "traditional" or "other" and "above standard" then it was identified by consultants as a "nice-to-have" rather than a "must have" - and consequently an area for potential cutbacks or restructuring.

By presenting information in this way, consultants were able to skillfully traverse distances by rendering disparate services proximate and subject to measurement. Through accumulating data that were taken from other places and times and presenting them all at once in a single schema, civic officials and community members were given a common point of reference through which they could see, for example, how the city's transit services measured up against its provision of community recreation or libraries. The apparent necessity of each of these services was plotted on the same chart, enabling people to make authoritative comparisons between radically different service areas without requiring in-depth knowledge of their operations.

"Standards" of service were also established by comparing accounts with a select sample of other cities deemed to be similar to Toronto "in terms of size, history, urban characteristics, demographics, geography"2 - including Montréal, Chicago, Boston, Philadelphia, Barcelona, and Melbourne -

\footnotetext{
${ }^{2}$ KPMG, 28 July 2011; presentation to the City of Toronto's Executive Committee.
}

which were listed in a "jurisdictional examples" section of the template. Here, KPMG noted the extent to which Toronto departed from the norm in the field of municipal service delivery by providing services that were deemed to be uncommon or provided at higher than standard levels in comparison with other cities. For instance, consultants noted, "available spaces in Toronto libraries are elevated" in comparison with other jurisdictions, and the "fare revenue / cost ratio" in public transit is higher (KPMG, 2011b:153; 162). Moreover, they noted best practices in other cities that Toronto might consider adopting, such as offloading heritage work, which was provided by an independent agency in a number of cities, or selling off parking facilities, which had been undertaken in Chicago (KPMG, 2011b:98; 113). By placing the city in proximity with other, previously distant, jurisdictions, then, its needs could be defined on the basis of outside standards.

Through presenting information on city services in this way, consultants were then capable of identifying various "options" and "opportunities" for savings, listed in a separate section, which included such things as

- cutting back on the city's "very aggressive" recycling target of $70 \%$ diversion from landfill sites;

- closing public library branches and reducing hours of operation;

- eliminating the Toronto Environment Office and Toronto Atmospheric Fund;

- eliminating or reducing the Toronto Transit Commissions late-night service and the Wheel Trans service for people with disabilities;

- contracting out snow clearing and park maintenance services;

- outsourcing residential solid waste and eliminating small commercial waste collection;

- cutting publicly subsidized childcare services, which had lost provincial government funding;

- selling off the Toronto Zoo, Exhibition Place, and cityowned theatres.

Moreover, in appraising these options, consultants developed a prospective timeline and identified various potential costs and political, economic, and social risks that were associated with their implementation.

As a relatively durable object, the core service filter acquired a presence, in part, through its capacity to traverse different institutional settings, dissolving the relationship between "near" and "far" as it was circulated as a common referent from place to place (Smith, 1987:2; see also Latour, 1987; Kitchin et al., 2015; Shore and Wright, 2011). It provided a means by which ideas from different local settings 
could be collected, archived, and mobilized - enabling officials to act on them in a coordinated fashion from an administrative centre without requiring an in-depth knowledge of the local context (Scott, 1998). In gauging the importance of services, the reader was not required to have any on-the-ground knowledge of service delivery in these different cities. They did not need to have any direct experience with transit services, community grants, homeless shelters, or public libraries.

However, the inscription in itself does not explain the influence of the core service filter here. As Latour (1986:15) notes, "it is the inscription as the fine edge and the final stage of a whole process of mobilization that modifies the scale of the rhetoric". The text is fabricated through the mobilization of knowledge from elsewhere, presenting artifacts of institutional and professional relations that are not immediately apparent at public gatherings. This involves a process of "reaching out" by which consultants lift out information that is generated at a number of different locations and translating it into a single account, one that is processed at a central node from where it can be disseminated (Espeland and Stevens, 1998; Latour, 1987; McCoy, 1998; Robson, 1992).

In the context of the Core Service Review, consultants noted that their data were gleaned from a variety of different sources, including the newly created Financial Planning Analysis and Reporting System (FPARS), established in 2005 as part of a municipal program to track, monitor, and evaluate the city's financial data with the aim of ensuring that service objectives are being met. Moreover, the work of consultants was informed by meetings and workshops with senior staff from the City Manager's Office (CMO), who provided advice to consultants on how to read these data. Consultants claimed to "add value" in their analysis by bringing these data into conversation with extra-local professional networks and databases, drawing from their own institutional archives and experienced specialists to undertake a review and analysis of jurisdictional examples. Moreover, they also worked to put these data into conversation with a growing array of global and regional ranking and benchmarking systems, such as the recently established Ontario Municipal Benchmarking Initiative (OMBI), through which Toronto's services could be compared with other municipalities across the province. Through the work of compiling and rendering data from distant sources and disparate domains commensurable and amenable to presentation in a single metric, they were then capable of taking a forceful position in speaking to the state of the city's services.

At the same time, the core service filter enabled consultants to make their presence felt by placing their knowledge and its attendant relations out of reach of civic officials and members of the community. The information generated by KPMG was institutionally segmented, with the conception and implementation of evaluations being organized at arm's length from the execution of services. The work of KPMG consultants is notable in this case to the extent that it did not investigate the experience of service provision at the front line but rather generated data through a second-order process that focused on rendering existing authoritative texts - setting out regulatory frameworks and providing financial data on service delivery - commensurable and legible from an administrative centre.

Through the segmentation of knowledge in this way, consultants were then able to generate "distance" in their account (D. E. Smith, 1990, 2005). Through placing the institutional relations in which it was produced at arm's length, outside of the field of knowledge at public meetings, the filter could stand in for lived experiences through its presentation as an "transparent" and "objective" metric for the appraisal of city services. As D. E. Smith (1990: 74) observes, the text effectively "drops away the traces of its making (references to evidence, research, researchers, the technical processes involved, and so forth) and stands forth as an autonomous statement representing the actuality of which it speaks". In the words of one KPMG consultant, the Toronto Core Service Review provided a "pure lens of cost saving":

So, you know, that ... was what made the scope doable in a couple of months ... Obviously very important services, very important to a lot of Torontonians - things like childcare, parks and rec, long-term care homes - and so, you know, we thought that there was certainly a rich argument to take place, or a rich debate, at the political level to really inform those ultimate choices, but ours was really, you know, just look through a lens of if you were looking only at cost savings - what's the core and non-core, and what service levels might be reduced? You know, the literature of the OECD, most economists, would agree that the best way of saving money is to stop doing something - to stop programs, to stop the service levels; that's kind of an enduring, sustainable way of saving costs. So that was frankly the lens that we took looking through. ${ }^{3}$

There is a sense here that the consultant was simply applying an objective lens in reporting the facts. Appealing to the pure metric of cost savings that KPMG had inherited through its long legacy in the fields of accounting and auditing, consultants claimed to sift through all of the extraneous material - "cutting through complexity", as their slogan goes - in exposing an underlying objective reality that is positioned at arm's length from the formal political process (Power, 1997; Shore, 2008; Strathern, 2000). Indeed, consultants readily acknowledged that it was not their place to get involved in political discussions regarding the priorities for service delivery; they were just providing the background context, setting

\footnotetext{
${ }^{3}$ Fossay, Craig and Glen Sloutsky. 2011. KPMG - City of Toronto Core Services Review, [Webinar to Institute for CitizenCentred Service]. 27 October. Retrieved from https://www.youtube. com/watch?v=H5gz76YQElU.
} 
the stage for debate. They were not providing "recommendations"; rather, they were just presenting "options" that could be taken into consideration by city councillors.

Through packaging and circulating the core service filter in this way, management consultants were able to skillfully articulate distanciated relationships, both near and far, in making their presence felt at the public meeting. On the one hand, by reaching out to disparate domains and jurisdictions, they were able to put the city in proximity with previously distant locations. By gathering data from other places and times and presenting it all in one place, they were able to create the sense that it stood together in a single metric, generating a common reference point in policy debates. On the other hand, consultants were able to put these data out of reach in various ways, through the segmentation of knowledge, which was packaged and presented as outside the experiences of civic officials, public service professionals, and community members. These two processes were vital, I argue, in the constitution of a trans-urban policy pipeline in Toronto, facilitating the smooth circulation of policy ideas and agendas across disparate institutional settings. Through packaging knowledge in this way, consultants were able to assemble "elements of different geographical reach into interlocking sets of relations that connect geographically discrete locations" (Cook and Ward, 2012:142). The evaluative text itself provides a rhetorical tool through which this sense of proximity is established.

\section{Disassembling the core service filter: coordinating responses and gathering alternatives}

The capacity to "lift out" and "fold in" knowledge from elsewhere is by no means a conclusive accomplishment. In fact, it is often tenuously connected through highly mediated work undertaken at a range of different sites that are vulnerable to contestation. For instance, in Toronto, the efforts of management consultants to achieve distance by reaching out for data in other jurisdictions were actively challenged by councillors, city staff, and community activists, who took issue with way in which information on the city's needs was gathered and presented. In confronting the efforts of intermediaries to achieve discursive closure, effectively setting their ideas apart in the policy-making process, it is also important to consider the way in which activists have themselves worked to lift out and fold in other kinds of knowledge in contesting consultants' claims.

In the hundreds of written and oral deputations collected by the city, those speaking not only made a case for the necessity of certain services that were classified as discretionary but also challenged the methodologies that were applied, raising questions about the capacity of KPMG to effectively appraise the success of service reforms in other cities and their applicability to the Toronto context. For instance, in challenging KPMG's suggestion that the city look into privatizing transit services, Councillor Adam Vaughan raised questions about the experience in Melbourne, which was introduced as a key comparator in their report:

Councillor: Is KPMG familiar with the Melbourne experience of privatizing service in that city, of its streetcar lines?

Consultant: Not particularly streetcar lines, but we certainly recognize that a lot of services buses, trains, subways - in Melbourne have been privatized, and according to reports that system is working fairly efficiently.

Councillor: Okay. So, in 1999, they privatized them. In 2001, are you familiar with why the subsidy had to be increased by USD 100 million per company that was operating the transit lines?

Consultant: Obviously that level of detail would be beyond the scope of the Core Service Review.

Councillor: Right. Are you familiar with why the firms pulled out and went into receivership in 2002 ?

Consultant: Nope. Did not go into that level of detail... Again...

Councillor: In 2004, are you familiar with why the subsidies to private companies operating the tramlines in Melbourne ... increased by a billion dollars?

Consultant: I would probably advise that if that information is relevant to the Council in making its decision that you make it available in your debates, in terms of making decisions on these examples.

Councillor: But you are suggesting that we explore the possibility of privatizing certain of our services, including I would expect tram lines, streetcar lines...

Consultant: I think that it would be incumbent on the Council to at least consider the possibility and develop a business case on whether that makes sense in the city or not.

Councillor: So, do you know why within a 10-year period, the subsidy went from USD 3 to 5 billion, a billion dollars over the estimated cost, and why tram fares - which originally were contracted at being no greater than the rate of inflation - that was removed, to an extra cost to tram riders of a hundred million dollars a year. Are you familiar with what caused those pressures?

Consultant: I believe we've answered that question. 
Councillor: Okay. So, I guess the next question would be, in 2010, when the contracts went to be expired, recommendations were made to the state government and to the transportation system to increase the amount of privatization despite the fact that the cost was now $30 \%$ more than originally projected, which was an additional cost to taxpayers of USD 2.1 billion, but the service levels - because of nighttime cuts, another recommendation you're making - [were] $30 \%$ less. Do you know why that happened in Melbourne?

Consultant: This was not a detailed review of the Melbourne transportation service, Councillor.

Councillor: So, the question is this: KPMG was the consultant that recommended the privatization of the tramlines in Melbourne. Why, with that inhouse experience from 161 and 159 Collins Street in Melbourne ... Why with that experience, would you replicate the proposal here in Toronto, knowing that you were $30 \%$ off on cost, $30 \%$ off on service, and you generated USD 100 million above and beyond inflation annually?

Mayor: Thank you. That's your three minutes.

It is notable, in this process of cross-examination, how the city councillor exposes the fragility of the linkages made by consultants, revealing the lack of in-depth knowledge about a case in which KPMG was ostensibly involved. Locating the KPMG offices at "161 and 159 Collins Street in Melbourne", the councillor articulates the problem of proximity here, exposing the thin circulation of policy ideas across the firm and revealing what consultants lost as they disembedded their findings from a specific urban context. While the enduring legacy of privatization in Melbourne is ignored by consultants, its synchronic placement in the text as one comparator among several makes it appear as a viable policy option.

Of course, as the mayor's swift interjection suggests, this is by no means an open process. In constituting an urban politico-administrative regime, Turner (2001) notes, civic officials are centrally concerned with generating accounts that are based on structured forms of dialogue in which public officials and local citizens are drawn into conversation with evaluative texts in setting priorities and making decisions (see also Turner, 2006; Smith, 2005; Murray, 2012). People are enlisted into the process in particular ways. They receive notice about the event through specific channels - through the city's website, community bulletin boards, email lists, social media, television, and newspapers - and become eligible to speak through specific processes of enrollment and registration. In the context of the Core Service Review, the CMO coordinated a series of public consultations, organized by service area, created an online survey and invited deputations to various standing committee meetings in which any member of the public was eligible to provide either spoken or written feedback.

For services under the jurisdiction of the city's Executive Committee, it is notable that the opportunity to respond to the policy options was crammed into a single $22 \mathrm{~h}$ meeting, in which each deputant was granted only 3 min (reduced from the standard $5 \mathrm{~min}$ ) to present their case. From the mayor's perspective, it was imperative to push through the consultative part of the process in order to get on with the business of urban restructuring. He was elected on a mandate of "stopping the gravy train" and he was adamant in his efforts to move ahead with the cutbacks, while at the same time attempting to provide a veneer of inclusivity (Kohler, 2010). As he noted, "I am going to sit here all day and all night and all morning until everyone has had a chance to speak." (cited in Morrow and Church, 2011). Enclosing the case for cuts within the temporal and spatial confines of the Council Chambers in an all-night meeting presented an opportunity to get it over and done with. Rather than dragging the process out through a lengthy series of investigations, reports, and consultations, the process facilitated temporal and spatial compression, what Vogelpohl (this issue) describes as an "intensified velocity of the policy process".

At the same time, the concentration of deputations in this specific time and space created an opportunity for community groups to make their presence felt in ways that otherwise might not have been possible. In the words of one community activist: "You bottle things up, they tend to explode more." In interviews, a number of activists described the deputations as a central moment in generating opposition to the city's budget process (Hartman, 2016; O'Reilly, 2016). One journalist tweeted from the meeting: "It is $11: 15 \mathrm{pm}$. Nearing $14 \mathrm{~h}$ of meeting. Energy in the room is buoyant, proud, energized. Room is full. A galvanized city. If [Mayor] Ford's goal in running overnight was to wear the deputants out, it backfired." (Dotan, 2011). Described as a "people's filibuster", and an "epic slumber party", hundreds of people packed city hall for over $22 \mathrm{~h}$ in order to make their presence felt and support other deputants. ${ }^{5}$ By cramming so many people into the building, community members generated a sense of nearness in the policy-making process, putting city councillors and policymakers in direct proximity with the community in a manner that made it difficult to ignore.

In the context of this meeting, citizens faced the challenge of effectively bringing their own forceful accounts into the process. This involved cultivating ways of speaking and forms of conduct that "worked", generating accounts that were "heard and responded to" by civic officials, the mainstream media, and the general public (Turner, 2001:306).

\footnotetext{
${ }^{4}$ Interview with community activist. 25 July 2016. Toronto, Canada.

${ }^{5}$ Kraus, K. (30 July 2011), “Activist Communiqué: Toronto City Council's Epic Slumber Party", http://rabble.ca/blogs/bloggers/ krystalline-kraus/2011/07/activist-communiqu
} 
Teaching community members effective strategies for making a case demanded a considerable amount of time and resources that were then folded into contested accounts. For instance, in preparation for the Executive Committee meeting, a "Step-by-Step Guide to Making a Deputation" - produced as part of a public campaign resisting cuts to community grants - offers one piece of advice:

In the body of the speech/deputation, make sure to outline the issue by using a true story or incident. Include statistics about the reality of the issue. Include the impact this issue has on the entire community [that] the body you're speaking to is representing (ward 12 residents, the entire city, homeless people, etc.). Refer to other work that has been done by others on the issue if possible, so that the body you are presenting to has some history and context for your recommendations." ${ }^{\prime 6}$

Speaking within the tight constraints of a 3-minute window, over 160 community members creatively framed and presented testimony that was intended to speak back to the KPMG report. While many accounts corresponded to the model presented above - including a brief biography, claims to represent a wider community of interest, and drawing from true stories and statistics - others included songs, poems, and even a puppet show that contested the process, calling attention to the ideological circularity of the KPMG account, questioning the credibility of its comparisons and seeking to demonstrate the various ways that cuts would negatively impact the Toronto community. For instance, one deputant compared the process to house renovations, with a contractor initially recommending the removal of "unsightly columns and pillars in the basement", and then going on to argue that, because the house is unstable, it is necessary to sell off everything that the pillars had supported - the fridge and stove, tables, and chairs. ${ }^{7}$

Deputants drew from different kinds of political, economic, and cultural capital - credentials, reputation, and other resources - in framing their accounts (Bourdieu, 1994; see also Ruppert, 2006). While some presented themselves as individual "taxpayers" or "citizens", others presented their report on behalf of a particular group or constituency. Accounts that challenged the findings of the report were

\footnotetext{
${ }^{6}$ Willats, Anna. "A Step-by-Step Guide to Making a Deputation," Retrieved from the Commitment 2 Community website: http://commitment2community.org/ a-step-by-step-guide-to-making-a-deputation/ (last access: 15 July 2016). It is notable that this guide was created by a member of the Toronto Police Accountability Coalition, where community members had already generated experience in the deputation process.

${ }^{7}$ For the full text, see "Torontonians at City Hall: Liveblogging the Executive Committee Budget Cut Meeting", http://torontoist.com/2011/07/torontonians_at_city_hall_ liveblogging_the_executive_committee_budget_cut_meetin/
}

presented by union leaders, anti-poverty activists, scholars, members of various civil society associations, and an array of professionals responsible for administering the city's services.

For instance, in responding to KPMG's suggestion that the city of Toronto consider divesting from Heritage Toronto, which it was argued could be transformed into a selfsustaining independent agency, the chair of the organization Peter Ortved argued that the proposals for finding money elsewhere were not realistic. The line of questioning from councillors that followed provides an interesting window into the politics of the review process, highlighting how both public officials and front-line practitioners worked together in generating accounts that questioned the credibility of the criteria that were used:

Councillor: “...[D]id [KPMG] contact you or your office and ask you about the context of the work that you do, the funds that are needed to run your affairs? Did they ever just sit down and ask you any questions at all?"

Deputant: "They did not sit down and ask me as the Chair of the Board, but they did have a brief meeting with ... our executive director who sits beside me."

Councillor: "And did they ever ask either of you if it's realistic in the context of what you said about the Federal Government and the Provincial Government - that also has some serious financial woes ... did they ever ask you if you seriously expect any funds coming from any other levels of government any time soon?"

Deputant: "I think they looked at some models of other cities and expressed some opinion that if Chicago gets some money from the state government, then maybe Toronto should get some from the provincial government."

Councillor: "Don't American cities have a completely different funding arrangement from their state and federal governments?"

Deputant: "Yes, of course they do. And same as the comparator to Montréal, which has a different relationship with the provincial government as well."

Councillor: "Do you understand, then, why are we comparing Toronto to governance models that may not apply or may not be directly analogous to our own?"

Deputant: "Well, we can compare them, but you have to draw some conclusions from those comparisons. And I don't think they're immediately very valid in terms of what can be changed in the next year or two in Toronto." 
Councillor: "It just seems to me like we're missing some thoughtful context and kind of throwing examples out in the air."

\section{Deputant: "I would agree."}

It is interesting, then, how the capacity for establishing commensurability between diverse jurisdictions is questioned by those who appeal to different kinds of professional and administrative authority; the dialogue is, in part, a coproduction of both city councillors and senior civic officials. This line of testimony is taken up again and again through the course of the Executive Committee meeting, with councillors interrogating the underlying logic of the review process through a series of pointed questions (for instance, in discussing proposed cuts to a city-funded meals-on-wheels program delivering hot food to the elderly: "Do you think that food is 'nice-to-have' or a 'must-have'?").

Moreover, beyond highlighting how evaluative texts are actively contested through these forms of structured dialogues, the presentations from deputants open a window onto the translocal organization of community activism, which itself folds in textually mediated accounts and forms of claimsmaking (G. W. Smith, 1990; Smith, 2005; Hussey, 2012). For instance, speaking on behalf of "over 2,400 library workers and the 1.25 million taxpayers who have a library card and use it regularly", the President of the Toronto Public Library Workers Union, Maureen O'Reilly, presented a petition with over 39000 signatures requesting that service levels be maintained, including endorsements from prominent Toronto authors such as Margaret Atwood (O'Reilly, 2013). ${ }^{8}$ The petition was widely circulated via a website set up by the library workers, through email lists and social media outlets. This text reflects a certain kind of politics of gathering knowledge of the city, involving the "lifting out" and "folding in" of texts by labour and community activists in opposing potential cutbacks.

\section{Conclusions}

The outcome of the Toronto Executive Committee meeting was unclear. Was the whole process just a farce, as some commentators suggested? Did it simply go through the motions of consulting the public in order to move on with the cutbacks? Certainly, an argument could be made that the process was window dressing, "providing political and ideological rationale" for neoliberal restructuring (Fanelli, 2016:52). Of course, this was noted by a variety of progressive community and labour-based organizations. As one activist proclaimed in a bullhorn outside of city hall: "This isn't about cost savings; this isn't about a deficit in the budget. This

\footnotetext{
${ }^{8}$ See the website set up by Toronto library workers, "Our Public Library": http://ourpubliclibrary.to/
}

is a political agenda to stop services in our community". 9 Even mainstream sources raised questions about the process. For instance, the Toronto Star noted in its verdict that the city's administration had delivered "a process that is rushed, incoherent, poorly thought out, heavy on political dogma." (Royson, 2011).

However, beyond the condemnations of KPMG for their ostensibly incriminating political and economic affiliations, it is also important to recognize all the work that was involved in unpacking their textually mediated claims. In the context of public meetings, management consultants sought to make their presence felt through specific practices of "lifting out" and "folding in" knowledge from other contexts. Through the production and circulation of relatively durable evaluative texts, they actively reached out to previously distant places, putting them in proximity as relational objects. By rendering these places commensurable through calculative registers, they enabled direct comparisons without requiring in-depth knowledge of their specific contexts. Moreover, through the segmentation of knowledge and its presentation in a self-contained package, they were able to place this knowledge out of reach from city councillors, community groups, and local residents, enabling it to stand in for institutional and professional relations and creating the sense that it provided a transparent and objective window onto the city's performance.

The production and circulation of knowledge in this way has posed a challenge for those who have sought to contest the options that are put on the table and advance their own claims in testifying to the importance of city services. It has demanded a considerable amount of work to disassemble the accounts of KPMG, which has involved interrogating the connections that are made with other places. It has demanded expertise in speaking to the suitability of the categories presented. Moreover, in generating alternative accounts, community groups have faced the challenge of developing ways of speaking - both inside and outside the official policy-making process - that are heard and responded to. This involves appealing to alternative ways of knowing the city that are assembled outside of council chambers and are themselves skillfully folded into the policy-making process.

The public meeting, then, also acts as a site for investigating the generation of accounts that do not correspond to official narratives of cutbacks and cost savings - accounts that present alternative knowledge of the urban context that can also be circulated from city to city. This is important to remember, because a focus on the transnational scale of policy networks alone, as mediated by professional service firms like KPMG, can lead to assumptions of institutional closure - presuming that all testimony is filtered into a single authoritative account. Beyond official texts such as the Final Report

\footnotetext{
9“"Toronto Stop the Cuts Network Confronts KPMG Consult This! Part 2," https://www.youtube.com/watch?v=xr-AAbQ2Opk
} 
produced by the City Manager's Office (Pennachetti, 2011), which transformed all the information generated from consultations and surveys into actionable policy options, a study of public meetings themselves illuminates a range of diverse registers through which accounts are presented and contested (McFarlane, 2011). Beginning with the deputations by different community groups, alternative accounts can be identified that run in parallel to and against the official narrative. Documenting these unofficial accounts is especially vital in the context of increasingly transnational flows of policy ideas, as they are not easily translated into knowledge that can be circulated across jurisdictions, and so risk being forgotten.

\section{Data availability}

Data collected for this study included: (1) official documents from both the city of Toronto and KPMG; (2) local and national newspaper articles; (3) assorted documents circulated across email lists by community activists; (4) official videos and transcripts of city meetings; and (5) interview transcripts from city officials and community activists. Official documents were accessed via the city of Toronto website. This included the full reports from KPMG as well as reports prepared by the City Manager's Office. Articles collected from Canadian newspapers - including the Toronto Star, Toronto Now, the Globe and Mail and the National Post - are all available online. Documents circulated by community activists were accessed via email listservs and from interview participants. While some of this data is available online, much of it has been removed from circulation and is no longer publicly available. Video clips from the KPMG Executive Committee are available via youtube (https://www.youtube.com/ watch? $v=$ WTCXzOX_UFM\&t=376s). The full video of the meetings can be ordered from the city of Toronto (http://app. toronto.ca/tmmis/index.do). For the purposes of protecting confidentiality, the interview transcripts cannot be made publicly available.

Competing interests. The authors declare that they have no conflict of interest.

Edited by: A. Vogelpohl

Reviewed by: three anonymous referees

\section{References}

Allen, J.: Topological twists: Power's shifting geographies, Dialogues in Human Geography, 1, 283-298, doi:10.1177/2043820611421546, 2011.

Allen, J.: Powerful City Networks: More than Connections, Less than Domination and Control, Urban Stud., 47, 2895-2911, doi: $10.1177 / 0042098010377364,2010$.
Allen, J. and Cochrane, A.: The Urban Unbound: London's Politics and the 2012 Olympic Games, Int. J. Urban Regional, 38.5, 1605-1624, doi:10.1111/1468-2427.12147, 2014.

Allen, J. and Cochrane, A.: Assemblages of State Power: Topological Shifts in the Organization of Government and Politics, Antipode, 42, 1071-1089, doi:10.1111/j.1467-8330.2010.00794.x, 2010.

Bourdieu, P.: Rethinking the State: Genesis and Structure of the Bureaucratic Field, Sociol. Theor., 12, 1-18, doi:10.2307/202032, 1994.

Boussebaa, M.: Professional service firms, globalization and the new imperialism, Accounting, Auditing \& Accountability Journal, 28, 1217-1233, doi:10.1108/AAAJ-03-2015-1986, 2015.

Cochrane, A. and Ward, K.: Researching the geographies of policy mobility: confronting the methodological challenges, Environ. Plann. A, 44, 5-12, doi:10.1068/a44176, 2012.

Cook I. and Ward, K.: Trans-urban Networks of Learning, Mega Events and Policy Tourism: The Case of Manchester's Commonwealth and Olympic Games Projects, Urban Stud., 48, 25192535, 2011.

Cook, I. and Ward, K.: Conferences, informational infrastructures and mobile policies: the process of getting Sweden "BID ready", Eur. Urban Reg. Stud., 19, 137-152, doi:10.1177/0042098011411941, 2012.

Craig, D.: Plundering the Public Sector, Constable, London, 2006.

Dale, D. and Rider, D.: Ford unswayed by 22 hours of talk, teen's tears, Toronto Star, available at: http: //www.thestar.com/news/gta/2011/07/30/ford_unswayed_ by_22_hours_of_talk_teens_tears.html, 30 July 2011 .

Dent, G.: Interview with the author, Toronto, Ontario, 18 July 2016.

DiMaggio, P. J. and Powell, W. W.: The Iron Cage Revisited: Institutional Isomorphism and Collective Rationality in Organizational Fields, Am. Sociol. Rev., 48, 147-160, 1983.

Doolittle, R.: Critics see KPMG report as "smoke and mirrors", Toronto Star, available at: https://www.thestar.com/news/city_ hall/2011/07/22/critics_see_kpmg_report_as_smoke_and_ mirrors.html, 22 July 2011.

Domhoff, G.: Who Rules America, Prentice-Hall, New Jersey, 1967.

Dotan, H.: "Torontonians at City Hall: Liveblogging the Executive Committee Budget Cut Meeting", Torontoist, available at: http://torontoist.com/2011/07/torontonians_at_city_hall_ liveblogging_the_executive_committee_budget_cut_meetin/, 29 July 2011.

Espeland, W. N. and Stevens, M. L.: Commensuration as a social process, Annu. Rev. Sociol., 24, 313-343, doi:10.1146/annurev.soc.24.1.313, 1998.

Eyal, G. and Buchholz, L.: From the Sociology of Intellectuals to the Sociology of Interventions, Annu. Rev. Sociol., 36, 117-137, doi:10.1146/annurev.soc.012809.102625, 2010.

Fanelli, C.: Megacity Malaise: Neoliberalism, Public Services and Labour in Toronto, Fernwood Publishing, Winnipeg, 2016.

Greer, P.: Transforming Central Government: The Next Steps Initiative, Open University Press, Buckingham, 1994.

Griffith, A. and Smith, D. E.: Introduction, in: Under New Public Management, University of Toronto Press, Toronto, 2014.

Guttman, D. and Willner, B.: The Shadow Government, Pantheon Books, New York, 1976. 
Hartmann, F.: Interview with the author, Toronto, Canada, 18 July 2016.

Hodge, G. and Bowman, D.: The "consultocracy": The business of reforming government, in: Graeme Privatization and Market Development, Edward Elgar, Northampton, MA, 2006.

Hood, C.: Explaining Economic Policy Reversals, Open University Press, Buckingham, 1994.

Hood, C. and Jackson, M. W.: Administrative Argument, Aldershot, Dartmouth, 1991.

Hussey, I.: "Political Activist as Ethnographer" Revisited, The Canadian Journal of Sociology/Cahiers canadiens de sociologie, 37, 1-23, http://www.jstor.org/stable/canajsocicahican.37.1. $1,2012$.

Jones, A.: The "global city" misconceived: The myth of "global management" in transnational service firms, Geoforum, 33, 335350, 2002.

Kennedy Consulting Research and Advisory: Global consulting market index 2013, New York, Kennedy Consulting Research and Advisories, 2013.

Kipping, M. and Wright, C.: Consultants in Context: Global Dominance, Societal Effect, and the Capitalist System, in: The Oxford Handbook of Management Consulting, edited by: Kipping, M. and Clark, T., Oxford University Press, Oxford, UK, doi:10.1093/oxfordhb/9780199235049.013.0008, 2012.

Kitchin, R., Lauriault, T. P., and McArdle, G.: Knowing and governing cities through urban indicators, city benchmarking and real-time dashboards, Regional Studies, Regional Science, doi:10.1080/21681376.2014.983149, 2015.

Kohler, N.: How Rob Ford won Toronto, Maclean's, available at: http://www.macleans.ca/news/canada/the-game-changer/, 29 October 2010.

KPMG: Proposal to Serve Corporation of the Town of Cochrane, available at: https://cochrane.civicweb.net/document/79765, last access: 8 July 2016.

KPMG: Final Report to the City Manager, City of Toronto Core Service Review Project, http://www1.toronto.ca/CityOfToronto/ CityManager' sOffice/CityManagerProfile/CityInitiatives/ backgroundfile-39505.pdf, 2011 a.

KPMG: Standing Committee Summary - Executive Committee, City of Toronto Core Service Review Project, www.toronto.ca/ legdocs/mmis/2011/ex/bgrd/backgroundfile-39626.pdf, 2011b.

KPMG: International Annual Review, available at: https://home.kpmg.com/xx/en/home/about/ international-annual-review-2015.html, 2015.

Kraus, K.: Activist Communiqué: Toronto City Council's Epic Slumber Party, Rabble.ca, http://rabble.ca/blogs/ bloggers/krystalline-kraus/2011/07/activist-communiqu\% C3\%A9-toronto-city-council\%E2\%80\%99s-epic-slumber-par, 30 July 2011.

Larner, W.: Globalizing knowledge networks: Universities, diaspora strategies, and academic intermediaries, Geoforum, 59, 157-205, doi:10.1016/j.geoforum.2014.10.006, 2015.

Larner, W. and Laurie, N.: Travelling technocrats, embodied knowledges: Globalising privatisation in telecoms and water, Geoforum, 41, 218-226, doi:10.1016/j.geoforum.2009.11.005, 2010.

Latour, B.: Science in Action, Harvard University Press, Cambridge, MA, 1987.

Latour, B.: Visualisation and Cognition: Drawing things together, Knowledge and Society, 6, 1-40, 1986.
Leys, C.: Intellectual Mercenaries and the Public Interest: Management Consultants and the NHS, Policy Polit., 27, 447-65, doi:10.1332/030557399782218353, 1999.

McCann, E.: Expertise, truth, and urban policy mobilities: global circuits of knowledge in the development of Vancouver, Canada's "four pillar" drug strategy, Environ. Plann. A, 40, 885-904, 2008.

McCann, E. and Ward, K. Urban Assemblages: Territories, Relations, Practices, and Power, in: Mobile Urbanism, University of Minnesota Press, Minneapolis, xiii-xxxv, 2011.

McCann, E. and Ward, K. Assembling urbanism: following policies and "studying through" the sites and situations of policy making, Environ. Plann. A, 44, 42-51, doi:10.1068/a44178, 2012.

McCann, E. and Ward, K.: A multi-disciplinary approach to policy transfer research: Geographies, assemblages, mobilities, and mutations, Policy Studies, 34, 2-18, doi:10.1080/01442872.2012.748563, 2013.

McCoy, L.: Producing "What the Deans Know": Cost Accounting and the Restructuring of Post-Secondary Education, Hum. Stud., 21, 395-418, doi:10.1023/A:1005433531551, 1998.

McFarlane, C.: Learning the City: Knowledge and Translocal Assemblage, Wiley-Blackwell, Oxford, doi:10.1002/9781444343434, 2011.

McKenna, C. D.: The World's Newest Profession, Cambridge University Press, Cambridge, doi:10.1017/CBO9780511511622, 2006.

Morrow, A. and Church, A.: Don't cut anything, presenters tell Toronto mayor at marathon meeting, Globe and Mail, available at: http://www.theglobeandmail.com/news/toronto/dontcut-anything-presenters-tell-toronto-mayor-at-marathonmeeting/article589415/?page=1, 28 July 2011.

Moss, T., Guy, S., Marvin, S., and Medd, W.: Intermediaries and the Reconfiguration of Urban Infrastructures: An Introduction, in: Shaping Urban Infrastructures: Intermediaries and the Governance of Socio-technical Networks, Earthscan, London, doi:10.4324/9781849775380, 2011.

Murray, K. M.: Regulating Activism: An Institutional Ethnography of Public Participation, Community Dev. J., 47, 199-215, doi:10.1093/cdj/bsr022, 2012.

O'Reilly, M.: Interview with the author, Toronto, Canada, 18 July 2016.

O'Reilly, M.: Engaging Patrons: Fight Back on the 2011-2012 Toronto Budget and Beyond, Partnership: The Canadian Journal of Library and Information Practice and Research, 8, 1-3, doi:10.21083/partnership.v8i1.2606, 2013.

O'Shea, J. and Madigan, C.: Dangerous Company: The Consulting Powerhouses and the Businesses they Save and Ruin, Times Business, New York, 1997.

Peck, J.: Geographies of policy: From transfer-diffusion to mobility-mutation, Prog. Hum. Geog., 35, 773-797, doi:10.1177/0309132510394010, 2011.

Peck, J. and Theodore, N.: Follow the policy: A distended case approach, Environ. Plann. A, 44, 21-30, doi:10.1068/a44179, 2012.

Peck, J. and Theodore, N.: Fast Policy, University of Minnesota Press, Minneapolis, 2015.

Pennachetti, J. P.: Core Service Review - Final Report to Executive Committee, City of Toronto, Toronto, available at: www.toronto. ca/legdocs/mmis/2011/ex/bgrd/backgroundfile-40702.pdf, 2011.

Pinault, L.: Consulting Demons: Inside the Unscrupulous World of Global Corporate Consulting, Harper Business, New York, 2000. 
Power, M.: The Audit Society: Rituals of Verification, Oxford University Press, Oxford, 1997.

Prince, R.: Policy transfer as policy assemblage: making policy for the creative industries in New Zealand, Environ. Plann. A, 42, 169-186, doi:10.1068/a4224, 2010.

Prince, R.: Policy transfer, consultants and the geographies of governance, Prog. Hum. Geog., 36, 188-203, doi:10.1177/0309132511417659, 2012.

Raco, M.: State-led Privatisation and the Demise of the Democratic State, Routledge, doi:10.1080/21622671.2015.1036912, 2013.

Raco, M., Street, E., and Freire-Trigo, S.: The New Localism, AntiPolitical Development Machines, and the Role of Planning Consultants: Lessons from London's South Bank, Territory, Politics, Governance, 4, 216-240, 2016.

Rassam, C. and Oates, D.: Management Consultancy: The Inside Story, Mercury Business Books, London, 1991.

Robson, K.: Accounting Numbers as "Inscription": Action at a Distance and the Development of Accounting, Account. Org. Soc., 17, 685-708, doi:10.1016/0361-3682(92)90019-O, 1992.

Royson, J.: "Service Review" lacks core credibility, Toronto Star, https://www.thestar.com/news/gta/2011/07/25/service_review_ lacks_core_credibility.html, 25 July 2011.

Ruppert, E. S.: The Moral Economy of Cities, University of Toronto Press, Toronto, 2006.

Saint-Martin, D.: Building the New Managerialist State, Oxford University Press, Oxford, 2000.

Savage, M. and Williams, K.: Elites: Remembered in Capitalism and Forgotten by Social Scientists, Sociol. Rev., 58, 1-24, doi:10.1111/j.1467-954X.2008.00759.x, 2008.

Scott, J.: Seeing Like a State, Yale University Press, New Haven, 1998.

Shore, C.: Audit culture and illiberal governance, Anthropological Theory, 8, 278-298, doi:10.1177/1463499608093815, 2008.
Shore, C. and Wright, S.: Introduction. Conceptualising policy: Technologies of governance and the politics of visibility, in: Policy Worlds: Anthropology and the Analysis of Contemporary Power, Berghahn Books, New York, 2011.

Smith, D. E.: The Conceptual Practices of Power, University of Toronto Press, Toronto, 1990.

Smith, D. E.: Institutional Ethnography: A Sociology for People, Altamira, Lanham, 2005.

Smith, G. W.: Political Activist as Ethnographer, Soc. Probl., 37, 629-648, doi:10.2307/800586, 1990.

Strathern, M.: Introduction: new accountabilities, in: Audit Cultures, Routledge, London, 2000.

Sturdy, A., Handley, K., Clark, T., and Fincham, R.: Management Consultancy: Boundaries and Knowledge in Action, Oxford University Press, Oxford, 2009.

Suddaby, R. and Greenwood, R.: Colonizing knowledge: Commodification as a dynamic of jurisdiction expansion in professional service firms, Hum. Relat., 54, 933-953, doi:10.1177/0018726701547007, 2001.

Thrift, N.: Knowing Capitalism, Sage, London, 2005.

Turner, S. M.: Mapping institutions as work and texts, in: Institutional Ethnography as Practice, Rowman and Littlefield, Toronto, doi:10.1080/10245280108523562, 2006.

Turner, S. M.: Texts and the Institutions of Municipal Government: the Power of Texts in the Public Process of Land Development, Studies in Cultures, Organizations and Societies, 7, 297-325, 2001.

Ward, K.: "Policies in motion", urban management and state restructuring: The trans-local expansion of business improvement districts, Int. J. Urban Regional, 30, 54-75, doi:10.1111/j.14682427.2006.00643.x, 2006. 